\title{
Stosowanie techniki zaciskania do zamykania przepływu gazu w gazociągach z poliamidu PA 12 o maksymalnym ciśnieniu roboczym 1,6 $\mathrm{MPa}$
}

\section{Using a squeeze-off to close the gas flow in gas pipelines made of PA12 polyamide with a maximum working pressure of $1.6 \mathrm{MPa}$}

\author{
Anna Wróblewska \\ Instytut Nafty i Gazu - Państwowy Instytut Badawczy
}

\begin{abstract}
STRESZCZENIE: Niniejszy artykuł poświęcono ocenie możliwości zastosowania techniki zaciskania do zamykania przepływu gazu na gazociągach zbudowanych z rur poliamidowych PA 12. W trakcie budowy gazociągów, podczas prac eksploatacyjnych na czynnych gazociągach, jak również użytkowania gazociągów istnieje czasami konieczność ograniczenia lub zamykania przepływu gazu. W gazociągach z polietylenu technika taka stosowana jest z powodzeniem od lat. Dla rur polietylenowych norma PN-EN 1555-2:2012 przedstawia ogólne wymagania dotyczące techniki zaciskania. Wymagania w stosunku do systemów rurociągów budowanych z poliamidu PA 12 określone są w normach z serii ISO 16486. Normy te nie podają żadnych, nawet ogólnych wymagań dotyczących techniki zaciskania. Norma ISO 16486 w części 6, tj. Kodeksie postępowania w zakresie projektowania, obstugi i instalacji, podaje jedynie, że w przypadku stosowania techniki zaciskania należy przestrzegać zaleceń producenta, ale brak jest szczegółowych wytycznych dotyczących wykonywania tego procesu. Technika zaciskania prowadzona według nieprawidłowych procedur lub w sposób niekontrolowany może mieć negatywny wpływ na wytrzymałość hydrostatyczną rur PA 12 lub doprowadzić do uszkodzenia rury. W ramach prac realizowanych w Instytucie Nafty i Gazu - Państwowym Instytucie Badawczym przewidziano przeprowadzenie badań rur z poliamidu po wykonanych operacjach zaciskania. Miało to posłużyć określeniu wpływu zaciskania na parametry wytrzymałościowe rur z poliamidu PA 12. W ramach realizacji pracy, na podstawie przeprowadzonej analizy, ustalono warunki, w jakich przebiegały procesy zaciskania. Na przygotowanych próbkach wykonano zaciskania realizowane w różnych warunkach i według różnych procedur. Następnie zostały przeprowadzone badania laboratoryjne zaciśniętych próbek, pozwalające ocenić wpływ procesu zaciskania na wytrzymałość hydrostatyczną rur PA 12. Na podstawie uzyskanych wyników i ich analizy stwierdzono, że nie zaobserwowano zmniejszenia odporności rur poliamidowych na ciśnienie wewnętrzne pod wpływem odkształceń w trakcie zaciskania rur PA 12, co pozwala na sformułowanie wniosku, że operacje zaciskania nie mają istotnego wpływu na wytrzymałość gazociągu budowanego z rur PA 12, a zatem na bezpieczeństwo jego użytkowania.
\end{abstract}

Słowa kluczowe: zaciskanie, gazociąg, poliamid PA 12.

\begin{abstract}
This article is devoted to assessing the possibility of using the clamping technique to close gas flow on gas pipelines built of PA12 polyamide pipes. During the construction of gas pipelines, operating works on active gas pipelines, as well as during the use of gas pipelines, there is sometimes a need to limit or close the gas flow. In polyethylene gas pipelines, this technique has been successfully used for years. For polyethylene pipes, the PN-EN 1555-2:2012 standard presents the general requirements for the clamping technique. The requirements for pipeline systems built of PA12 polyamide are specified in the standards of the ISO 16486 series. These standards do not give any, even general requirements, for the technique of clamping. The ISO 16486 standard in part 6, i.e. the Code of Practice for Design, Operation and Installation, only states that when using the clamping technique, the manufacturer's instructions must be followed but there are no detailed guidelines for performing this process. The clamping technique carried out according to incorrect procedures or in an uncontrolled manner may have a negative effect on the hydrostatic strength of PA12 pipes or lead to pipe damage. As part of the work carried out at the Oil and Gas Institute - National Research Institute, it is planned to carry out tests on polyamide pipes after clamping operations. This was to help determine the impact of clamping on the strength parameters of PA12 polyamide pipes. As part of the implementation of the work based on the conducted analysis, the conditions in which the clamping processes were carried out were established. Clamping was carried out on various samples under various conditions and according to different procedures.
\end{abstract}

Autor do korespondencji: A. Wróblewska, e-mail: anna.wroblewska@inig.pl

Artykuł nadesłano do Redakcji 11.01.2019 r. Zatwierdzono do druku 16.07.2019 r. 
Laboratory tests of clenched samples were then carried out, allowing to assess the impact of the clamping process on the hydrostatic strength of PA12 pipes. On the basis of the obtained results and their analysis, it was found that no reduction of polyamide pipe resistance to internal pressure under the influence of deformations during pipe clamping PA12 was observed, which allows to conclude that clamping operations have no significant impact on the strength of the pipeline built of PA12 pipes, therefore for the safety of its use.

Key words: squeeze-off, gas pipeline, polyamide PA12.

\section{Wstęp}

Technika zaciskania (squeeze-off) polega na zaciśnięciu rury pomiędzy równoległymi elementami aż do momentu uzyskania kontaktu powierzchni wewnętrznych ścianek rury.

Elastyczność i wytrzymałość większości rur polietylenowych pozwala na przywrócenie ich do kształtu cylindrycznego po operacji zaciskania bez istotnego obniżenia ich parametrów wytrzymałościowych (Klupa i Szewczyk, 2009). Technika zaciskania jest od lat $\mathrm{z}$ powodzeniem stosowana $\mathrm{w}$ wielu krajach do zamykania przepływu gazu w gazociągach z tworzyw sztucznych (polietylenu) (Lewandowski et al., 2006; Baranowski, 2009; Dowe et al., 2011; Bilsing et. al., 2018). Norma PN-EN 1555-2:2012 przedstawia ogólne wymagania dotyczące techniki zaciskania. Wymagania dla systemów rurociągów budowanych z poliamidu PA określone są w normach z serii ISO 16486 Plastics piping systems for the supply of gaseous fuels. Normy te nie podają żadnych, nawet ogólnych wymagań dotyczących techniki zaciskania. Norma ISO 16486 w części 6, tj. Kodeksie postępowania w zakresie projektowania, obstugi i instalacji, mówi, że w przypadku stosowania techniki zaciskania należy przestrzegać zaleceń producenta, ale brak jest szczegółowych wytycznych dotyczących wykonywania tego procesu. Technika zaciskania prowadzona według nieprawidłowych procedur lub w sposób niekontrolowany może mieć negatywny wpływ na wytrzymałość hydrostatyczną rur PA 12 lub doprowadzić do uszkodzenia rury. Ewentualne zmniejszenie wytrzymałości na ciśnienie wewnętrzne pod wpływem odkształceń w trakcie zaciskania rur PA 12 miałoby istotny wpływ na wytrzymałość gazociągu, a zatem na bezpieczeństwo jego użytkowania.

Dużym potencjalnie obszarem zastosowania dla rur z poliamidu PA 12 jest budowa gazociągów o maksymalnym ciśnieniu roboczym od 1,0 MPa do 1,6 MPa. W ostatnich latach rury wykonane z poliamidu PA 12 poddawane są dokładnym badaniom pod kątem ich zastosowania w gazowych instalacjach wysokociśnieniowych o ciśnieniu roboczym sięgającym nawet 20 bar. Po uzyskaniu ogólnie pozytywnych wyników w studiach wykonalności i rozmaitych instalacjach próbnych zagraniczny przemysł gazowy przeszedł do wykonania pierwszych instalacji eksploatacyjnych, aby uzyskać większe doświadczenie i zaufanie do tego nowego materiału, znajdującego zastosowanie jako zamiennik stali w wysokociśnieniowych liniach rozdzielczych (Wuest et. al., 2018). Z myślą o zdobyciu dalszych doświadczeń i zaufania w odniesieniu do funkcjonowania rur z PA 12 instalowanych z zastosowaniem alternatywnych technologii producent granulatu używanego do wytwarzania elementów sieci gazowej zbadał zachowanie rur wyprodukowanych $\mathrm{z}$ własnego poliamidu PA $12 \mathrm{w}$ instalacjach realizowanych metodą bezwykopową (Dowe et. al., 2011).

\section{Wymagania dla rur poliamidowych PA 12 dotyczące badań po zastosowaniu techniki zaciskania według ISO 16486-6:2012}

Wymagania jakościowe dla materiałów poliamidowych oraz wyprodukowanych z nich elementów sieci gazowych zawarte są w normach z serii ISO 16486 Plastics piping systems for the supply of gaseous fuels. Normy tej serii nie podają jednak nawet ogólnych wymagań dotyczących techniki zaciskania. Norma ISO 16486 w części 6, tj. Kodeksie postępowania w zakresie projektowania, obstugi i instalacji, określa, że w przypadku stosowania techniki zaciskania należy przestrzegać zaleceń producenta.

\section{Wymagania dla rur poliamidowych PA 12 dotyczące badań po zastosowaniu techniki zaciskania według prCEN TS12007-X:2018}

W opracowywanym projekcie normy prCEN TS12007-X:2018 zawarte są wymagania funkcjonalne dotyczące sieci gazowych budowanych z poliamidu. Projekt określa zakres stosowania rur poliamidowych do rozprowadzania gazu. Zebrano tu wymagania dotyczące budowy sieci gazowych z poliamidu oraz zawarto kryteria oceny jakości połączeń zgrzewanych doczołowo i elektrooporowo. Dokument ten ma być używany w połączeniu z krajowymi standardami i kodeksami postępowania. W dokumencie prCEN TS12007-X:2018 zaciskanie zdefiniowano następująco: czynność zaciskania rur mająca na celu przerwanie przepływu gazu. W punkcie dotyczącym właściwości materiału rur po zaciśnięciu podano, że podczas rozpatrywania technik zaciskania należy ustalić przydatność rury do zaciskania zgodnie z normą PN-EN 1555-2, załącznik C, ponieważ opisana metodologia dotyczy również poliamidu PA-U. 
Odnosząc wymagania z PN-EN 1555-2:2012 do rur poliamidowych - jeśli odbiorca rur ma zamiar zastosować technikę zaciskania w celu wstrzymania przepływu gazu, zaleca się, aby ich producent przedstawił dowód, że po zaciśnięciu rur zgodnie z jego zaleceniami lub z zastosowaniem opaski wzmacniającej nadal spełnione są wszystkie wymagania odnośnie do wytrzymałości hydrostatycznej, zgodnie z tablicą 4 normy ISO 16486-2:2012.

W celu potwierdzenia należy przeprowadzić badania, stosując metodę podaną w normie PN-EN 12106:2002 Systemy przewodów rurowych z tworzyw sztucznych. Rury z polietylenu (PE). Metoda badania wytrzymałości na ciśnienie wewnętrzne po zastosowaniu zacisku.

Dalej w projekcie dokumentu CEN TS12007-X:2018, tak jak w normie PN-EN 12007-2:2013-02, dotyczącej rur polietylenowych, podano, że procedury oraz oprzyrządowanie do zaciskania powinny być określone przez operatora rurociągu. W projekcie tym przedstawiono następujące ograniczenia dotyczące techniki zaciskania: miejsca zaciskania powinny być zlokalizowane w odległościach nie mniejszych niż $3 \times d_{n}$ od połączeń zgrzewanych oraz $\mathrm{w}$ odległościach nie mniejszych niż $6 \times d_{n}$ od innych miejsc zaciskania, dodano również zastrzeżenie, że jeżeli odcinek zaciskanej rury nie jest wymieniany, to miejsce zaciskania powinno być trwale oznakowane.

\section{Metoda badania wpływu wykonanej operacji zaciskania według normy PN-EN 12106:2002}

W celu potwierdzenia, że rury polietylenowe po wykonanej operacji zaciskania nadal spełniają wszystkie wymagania odnośnie do wytrzymałości, przeprowadzane są badania według normy PN-EN 12106:2002. Pozytywne wyniki badań pozwalają zaakceptować stosowanie techniki zaciskania rur do zamykania przepływu gazu dla rur PE danego producenta.

Sposób wykonania: rurę z polietylenu po kondycjonowaniu w temperaturze $0 \pm 1,5^{\circ} \mathrm{C}$ zaciska się w środku jej długości pomiędzy dwoma równoległymi wałkami o przekroju kołowym. Po określonym czasie zacisk się zwalnia. Następnie rurę poddaje się badaniu wytrzymałości na ciśnienie hydrostatyczne w temperaturze $80^{\circ} \mathrm{C}$.

Przyrząd do zaciskania powinien posiadać mechanizm wywołujący siłę ściskającą, z układem wałka stałego i ruchomego objętych ramą skonstruowaną w taki sposób, by przenosiła siły wywołane procesem zaciskania. Oba wałki powinny mieć przekrój kołowy i sztywność zapewniającą w czasie zaciskania równomierną szczelinę pomiędzy wałkami i wzdłuż nich. Obydwa wałki powinny mieć tę samą średnicę, której wartość minimalną podano w tabeli 1.
Tabela 1. Minimalne średnice walcowych elementów zaciskających w zależności od średnicy zaciskanej rury (PN-EN 12106:2002)

Table 1. Minimum diameters of cylindrical clamping elements depending on the diameter of the pipe being squeezed-off

\begin{tabular}{|c|c|}
\hline Nominalna średnica zewnętrzna $\boldsymbol{d}_{\boldsymbol{n}}$ & Minimalna średnica wałka \\
\hline$[\mathrm{mm}]$ & {$[\mathbf{m m}]$} \\
\hline \hline$d_{n} \leq 63$ & 25,0 \\
\hline $63<d_{n} \leq 250$ & 38,0 \\
\hline $250<d_{n} \leq 630$ & 50,0 \\
\hline
\end{tabular}

Próbką do badań jest odcinek rury z końcami obciętymi prostopadle do jej osi. Swobodna długość próbki pomiędzy uchwytami zamykającymi, stosowanymi podczas badania wytrzymałości hydrostatycznej, powinna być równa sześciokrotności nominalnej średnicy zewnętrznej rury $d_{n}$, ale nie może być mniejsza niż $250 \mathrm{~mm}$. Należy określić średnią średnicę zewnętrzną próbki oraz minimalną grubość ścianki danej próbki rurowej. Przygotowaną próbkę rury kondycjonujemy w temperaturze $0 \pm 1,5^{\circ} \mathrm{C}$ przez czas co najmniej tak długi, jak to wynika z normy (PN-EN ISO 1167-1:2007).

W celu zapewnienia wymaganego stopnia zacisku $L$, zgodnie z tabelą 2 (PN-EN 12106:2002), należy ustawić ograniczniki ścisku hydraulicznego i zacisnąć na odległość $e_{q}$ obliczoną według równania (1):

$$
e_{q}=0,02 \mathrm{~L} \cdot e_{\min }[\mathrm{mm}]
$$

gdzie:

$e_{\min }-$ minimalna grubość ścianki określona dla danej rury [mm],

$L-$ stopień zacisku zgodny z tabelą 2 [\%].

Tabela 2. Zalecane stopnie zacisku $L$ w zależności od średnicy rury (PN-EN 12106:2002)

Table 2. Recommended $L$ squeeze-off steps depending on the pipe diameter

\begin{tabular}{|c|c|c|}
\hline $\begin{array}{c}\text { Nominalna średnica } \\
\text { zewnętrzna } \boldsymbol{d}_{\boldsymbol{n}}\end{array}$ & $\begin{array}{c}\text { Minimalna } \\
\text { średnica wałka }\end{array}$ & Stopień zacisku $\boldsymbol{L}^{\mathbf{1})}$ \\
\hline$[\mathbf{m m}]$ & {$[\mathbf{m m}]$} & {$[\%]$} \\
\hline$d_{n} \leq 63$ & 25,0 & 80 \\
\hline $63<d_{n} \leq 250$ & 38,0 & 80 \\
\hline $250<d_{n} \leq 630$ & 50,0 & 90 \\
\hline
\end{tabular}

${ }^{1)}$ Stopień zacisku $L$, w procentach, jest stosunkiem odległości pomiędzy wałkami zaciskającymi, w milimetrach, a podwójną minimalną grubością ścianki rury, $e_{\min }, \mathrm{w}$ milimetrach.

Po zakończeniu czasu kondycjonowania próbkę ustawia się pomiędzy wałkami zaciskającymi tak, aby między ich osiami a osią rury uzyskać kąt prosty oraz aby wałki znajdowały się w środku odległości pomiędzy końcami próbki. Następnie 
w temperaturze otoczenia nie wyższej niż $25^{\circ} \mathrm{C}$ zaciska się wałki z prędkością od $25 \mathrm{~mm} / \mathrm{min}$ do $50 \mathrm{~mm} / \mathrm{min}$ do odległości $e_{q} \mathrm{w}$ czasie liczonym od momentu wyjęcia z komory klimatycznej nie dłuższym, niż to podano w tabeli 3 .

Tabela 3. Czas zaciskania w zależności od średnicy zaciskanej rury Table 3. Squeeze-off time depending on the diameter of the pipe being squeezed-off

\begin{tabular}{|c|c|}
\hline Średnica zaciskanej rury $\boldsymbol{d}_{\boldsymbol{n}}$ & Czas zaciskania \\
\hline$[\mathrm{mm}]$ & {$[\mathbf{s}]$} \\
\hline \hline$d_{n} \leq 110$ & 90 \\
\hline $110<d_{n} \leq 250$ & 180 \\
\hline$d_{n}>250$ & 300 \\
\hline
\end{tabular}

Próbki do badań, na których realizowano procedury zaciskania, były następujące:

- proste odcinki rur o średnicach nominalnych $d_{n} 110 \mathrm{~mm}$ i $d_{n} 160 \mathrm{~mm}$ z końcami obciętymi prostopadle do ich osi, na których wykonano 1 lub 2 zaciski;

- proste odcinki rur o średnicach nominalnych $d_{n} 110 \mathrm{~mm}$ i $d_{n} 160 \mathrm{~mm}$ z wykonanym połączeniem metodą zgrzewania doczołowego, na którym wykonano 1 zacisk;

- proste odcinki rur o średnicach nominalnych $d_{n} 110 \mathrm{~mm}$ i $d_{n} 160 \mathrm{~mm}$ z dogrzanym metodą zgrzewania doczołowego połączeniem PA/stal, na którym wykonano 1 zacisk.

Zestawienie i charakterystykę próbek do badań zawiera tabela 4 .
Przez $(60 \pm 5)$ min należy utrzymywać stały stopień zacisku. Bezpośrednio po upływie tego czasu należy stopniowo zwalniać zacisk w taki sposób, aby zacisk wywołany wałkami całkowicie zwolnić przed upływem 1 min.

Następnie należy przygotować próbkę do przeprowadzenia badania wytrzymałości hydrostatycznej w temperaturze $80^{\circ} \mathrm{C}$ i wykonać badanie według PN-EN ISO 1167-1:2007.

Po badaniu należy skontrolować próbkę i zanotować miejsce i rodzaj jakiegokolwiek uszkodzenia, jeżeli ono wystąpiło.

Za wynik końcowy oznaczenia przyjmuje się:

- wynik pozytywny - osiągnięcie wymaganego czasu bez uszkodzenia próbki;

- wynik negatywny - czas do wystąpienia uszkodzenia badanej próbki.

W związku z tym, że projekt normy prCEN TS12007-X:2018 mówi, że oceniając właściwości rur PA 12 po zaciskaniu, należy ustalić przydatność rury do zaciskania zgodnie z PN-EN 1555-2 załącznik C, metoda ta może być użyta do określenia wpływu zaciskania rur PA 12 na ich wytrzymałość.

\section{Wytypowanie niezbędnych materiałów do badań}

Rury z poliamidu PA 12 produkowane są obecnie w zakresie średnic 32-160 mm. W ramach realizacji pracy badania przeprowadzono na próbkach rur o wymiarach: $d_{n} 110 \mathrm{~mm}$ i $d_{n} 160 \mathrm{~mm}$ wykonanych w szeregu wymiarowym SDR 11. Wytypowane do badań średnice są najczęściej stosowanymi w rurach poliamidowych, średnica $d_{n} 160 \mathrm{~mm}$ jest maksymalną produkowaną średnicą.
Tabela 4. Zestawienie i charakterystyka próbek do badań

Table 4. List and characteristics of test samples

\begin{tabular}{|c|c|c|c|c|c|}
\hline \multirow{2}{*}{$\begin{array}{c}\text { Nr } \\
\text { próbki }\end{array}$} & $\boldsymbol{d}_{n}$ & SDR & Rodzaj próbki & \multicolumn{2}{c|}{$\begin{array}{c}\text { Wymiary } \\
\text { rzeczywiste rury }\end{array}$} \\
\cline { 5 - 6 } & & & & $\boldsymbol{d}[\mathrm{mm}]$ & $\boldsymbol{e}[\mathrm{mm}]$ \\
\hline \hline 1 & 110 & 11 & rura & 110,0 & 10,10 \\
\hline 2 & 160 & 11 & rura & 160,2 & 15,10 \\
\hline 3 & 110 & 11 & rura & 110,0 & 10,10 \\
\hline 4 & 160 & 11 & rura & 160,8 & 15,00 \\
\hline 5 & 110 & 11 & rura zaciśnięta płaskownikiem & 110,5 & 10,06 \\
\hline 6 & 110 & 11 & rura & 110,5 & 12,20 \\
\hline 7 & 110 & 11 & rura & 110,3 & 10,30 \\
\hline 8 & 160 & 11 & rura & 160,5 & 14,90 \\
\hline 9 & 110 & 11 & rura + zgrzew + PA/stal & 110,3 & 10,25 \\
\hline 10 & 110 & 11 & rura z podwójnym zaciskiem & 110,5 & 10,50 \\
\hline 11 & 160 & 11 & rura z podwójnym zaciskiem & 161,0 & 15,10 \\
\hline 12 & 110 & 11 & rura z podwójnym zaciskiem & 110,5 & 10,10 \\
\hline 13 & 110 & 11 & rura + zgrzew + PA/stal & 110,5 & 10,05 \\
\hline 14 & 160 & 11 & rura + zgrzew + PA/stal & 161,0 & 15,10 \\
\hline 15 & 110 & 11 & rura & 110,2 & 10,10 \\
\hline 16 & 110 & 11 & rura & 110,3 & 10,30 \\
\hline 17 & 160 & 11 & rura & 110,5 & 10,50 \\
\hline & & & & & \\
\hline
\end{tabular}

Przygotowując próbki do zaciskania, przestrzegano wytycznych zawartych w prCEN TS12007-X:2018, tj. miejsca zaciskania były zlokalizowane w odległościach nie mniejszych niż $3 \times d_{n}$ od połączeń zgrzewanych, w tym od połączenia PA/stal, oraz w odległościach nie mniejszych niż $6 \times d_{n}$ od innych miejsc zaciskania.

Wykonanie połączeń zgrzewanych doczołowo wymagało zastosowania przewidzianych dla poliamidu PA 12 procedur zgrzewania. Proces zgrzewania doczołowego rur PA 12 jest analogiczny do procesu zgrzewania rur polietylenowych. Różnice dotyczą głównie parametrów zgrzewania takich jak: temperatura, nacisk jednostkowy na powierzchni zgrzewanych 
elementów, czasów trwania poszczególnych operacji. Ze względu na właściwości materiału PA 12 różnice występują również w przygotowaniu elementów do zgrzewania.

Podczas przygotowywania próbek ze zgrzewem doczołowym zastosowano procedury i parametry zgrzewania doczołowego rur PA 12 opracowane w INiG - PIB w ramach realizowanej pracy pt. Weryfikacja dostęnych procedur prowadzenia prób szczelności rurociagów z tworzyw sztucznych o $M O P=1,6 \mathrm{MPa}$, której wyniki zostały przedstawione w artykule P. Szewczyka (2018).

\section{Zaciskanie rur}

Opierając się na przeprowadzonej analizie dostępnych procedur zaciskania, zdecydowano, że operacje zaciskania rur poliamidowych zostaną wykonane na podstawie procedur zaciskania przedstawionych $\mathrm{w}$ dokumentach: PN-EN 12106:2002, w projekcie ST-IGG-2103 i według parametrów ustalonych w oparciu o dokument DVGW GW 332. Zaciskaniu poddawane były próbki rurowe nieobciążone ciśnieniem medium.

Ogólne zasady prowadzenia procesu zaciskania przedstawiają się w następujący sposób:

- urządzenie do zaciskania powinno spełniać określone wymagania w odpowiedniej specyfikacji technicznej;
Tabela 5. Parametry procesu zaciskania - 1 - według normy PN-EN 12106:2002

Table 5. Parameters of Squeeze-off - $\mathbf{1}$ - according to the PN-EN 12106 standard

\begin{tabular}{|l|c|}
\hline \multicolumn{1}{|c|}{ Parametr } & Wartość \\
\hline \hline Temperatura kondycjonowania przed zaciskaniem & $0^{\circ} \mathrm{C}$ \\
\hline Czas kondycjonowania przed zaciskaniem w $0{ }^{\circ} \mathrm{C}$ dla rur $d_{n} 110$ i $d_{n} 160$ & $6 \mathrm{~h}$ \\
\hline Temperatura zaciskania & $25 \pm 2{ }^{\circ} \mathrm{C}$ \\
\hline Stopień zacisku L/SOL & $80 \%$ \\
\hline Maksymalna prędkość zaciskania rur & $25-50 \mathrm{~mm} / \mathrm{min}$ \\
\hline Maksymalna prędkość luzowania zacisku & $12 \mathrm{~mm} / \mathrm{min}$ \\
\hline Czas zaciskania $d_{n} 110$ & $90 \mathrm{~s}$ \\
\hline Czas zaciskania $d_{n} 160$ & $180 \mathrm{~s}$ \\
\hline Czas utrzymywania pod zaciskiem & $60 \pm 5 \mathrm{~min}$ \\
\hline Czas zwalniania zacisku & $<1 \mathrm{~min}$ \\
\hline Minimalna średnica elementu zaciskającego dla rur o średnicy $d_{n} \leq 63 \mathrm{~mm}$ & $32 \mathrm{~mm}$ \\
\hline Minimalna średnica elementu zaciskającego dla rur o średnicy $d_{n} 75-160 \mathrm{~mm}$ & $50 \mathrm{~mm}$ \\
\hline
\end{tabular}

Tabela 6. Parametry procesu zaciskania - 2 - ustalone na podstawie projektu ST-IGG-2103

Table 6. Parameters of Squeeze-off - 2 - determined based on the ST-IGG-2103 project

\begin{tabular}{|l|c|}
\hline \multicolumn{1}{|c|}{ Parametr } & Wartość \\
\hline \hline Temperatura kondycjonowania przed zaciskaniem & $0{ }^{\circ} \mathrm{C}$ \\
\hline Czas kondycjonowania przed zaciskaniem $\left[0{ }^{\circ} \mathrm{C}\right]$ & $8 \mathrm{~h}$ \\
\hline Temperatura zaciskania & $0^{\circ} \mathrm{C}$ \\
\hline Stopień zacisku L/SOL & $80 \%$ \\
\hline Maksymalna prędkość zaciskania rur w zależności od temperatury otoczenia $0-10^{\circ} \mathrm{C}$ & $5 \mathrm{~mm} / \mathrm{min}$ \\
\hline Maksymalna prędkość zaciskania rur w zależności od temperatury otoczenia $>10-25^{\circ} \mathrm{C}$ & $10 \mathrm{~mm} / \mathrm{min}$ \\
\hline Maksymalna prędkość zaciskania rur w zależności od temperatury otoczenia $>25^{\circ} \mathrm{C}$ & $15 \mathrm{~mm} / \mathrm{min}$ \\
\hline Maksymalna prędkość luzowania zacisku w zależności od temperatury otoczenia $0-10^{\circ} \mathrm{C}$ & $5 \mathrm{~mm} / \mathrm{min}$ \\
\hline Maksymalna prędkość luzowania zacisku w zależności od temperatury otoczenia $>10^{\circ} \mathrm{C}$ & $10 \mathrm{~mm} / \mathrm{min}$ \\
\hline Maksymalna prędkość przywracania przekroju kołowego & $50 \mathrm{~mm} / \mathrm{min}$ \\
\hline Maksymalny czas utrzymywania pod zaciskiem & $8 \mathrm{~h}$ \\
\hline Minimalna średnica walcowego elementu zaciskającego dla rur o średnicy $d_{n} 75-110 \mathrm{~mm}$ & 38 \\
\hline Minimalna średnica elementu zaciskającego dla rur o średnicy $d_{n} 125-200 \mathrm{~mm}$ & 50 \\
\hline Minimalny promień krawędzi elementu zaciskającego dla rur o średnicy $d_{n} 75-160 \mathrm{~mm}$ & 19 \\
\hline
\end{tabular}


Tabela 7. Parametry procesu zaciskania - $\mathbf{3}$ - ustalone na podstawie DVGW GW 332

Table 7. Parameters of the squeeze-off - 3 - determined based on DVGW GW 332

\begin{tabular}{|l|c|}
\hline \multicolumn{1}{|c|}{ Parametr } & Wartość \\
\hline \hline Temperatura kondycjonowania przed zaciskaniem & $5^{\circ} \mathrm{C}$ \\
\hline Czas kondycjonowania przed zaciskaniem & $8 \mathrm{~h}$ \\
\hline Temperatura zaciskania & $5^{\circ} \mathrm{C}$ \\
\hline Stopień zacisku L/SOL & $80 \%$ \\
\hline Maksymalna prędkość zaciskania rur & $50 \mathrm{~mm} / \mathrm{min}$ \\
\hline Maksymalna prędkość luzowania zacisku & $12 \mathrm{~mm} / \mathrm{min}$ \\
\hline Maksymalna prędkość przywracania przekroju kołowego & $12 \mathrm{~mm} / \mathrm{min}$ \\
\hline Czas trwania zacisku & $2 \mathrm{godziny}$ \\
\hline Minimalna średnica elementu zaciskającego dla rur o średnicy $d_{n} \leq 63 \mathrm{~mm}$ & $32 \mathrm{~mm}$ \\
\hline Minimalna średnica elementu zaciskającego dla rur o średnicy $d_{n} 75-160 \mathrm{~mm}$ & $50 \mathrm{~mm}$ \\
\hline
\end{tabular}

- po usunięciu urządzenia zaciskowego rura w miejscu zaciskania powinna być poddana oględzinom w celu wykrycia ewentualnych uszkodzeń;

- nie należy zaciskać rury ponownie w tym samym miejscu. Zakresy parametrów procesów zaciskania realizowanych zgodnie z tymi dokumentami zawarte są w tabelach 5, 6 oraz 7 . Próbki zaciskane według parametrów zawartych w projekcie standardu ST-IGG-2103 oraz według parametrów ustalonych na podstawie DVGW GW 332 po wykonanej operacji zaciskania, po całkowitym zluzowaniu zacisku, były poddawane procesowi przywracania rurze poliamidowej przekroju kołowego poprzez obrócenie rury o 90 stopni w stosunku do zaciskanego miejsca i częściowe zaciśnięcie rury z prędkościami podanymi w tabelach 5, 6 oraz 7 . W trakcie przywracania przekroju kołowego rura nie jest całkowicie zaciskana.

Przeprowadzenie badań laboratoryjnych rur poliamidowych po zastosowaniu technologii zaciskania obejmowało:

- ocenę wizualną zewnętrznej i wewnętrznej powierzchni rury w miejscu zaciskania;

- badania wytrzymałościowe zgrzewów określające przydatność systemu do stosowania, odporność na ciśnienie wewnętrzne - wytrzymałość hydrostatyczną $\left(80^{\circ} \mathrm{C}, 165 \mathrm{~h}\right)$.

Pozytywne wyniki zrealizowanych badań potwierdzą odporność rur poliamidowych na operację zaciskania. Przyjęto, że miarą odporności rur poliamidowych na zaciskanie jest odporność rur na ciśnienie hydrostatyczne w temperaturze $80^{\circ} \mathrm{C}$ i naprężeniu obwodowym 11,5 MPa zgodnie z wymaganiami zawartymi w normie w tablicy 4 normy ISO 16486-2:2012.

\section{Ocena wizualna}

Pierwszy etap badań obejmował ocenę wizualną po wykonaniu zaciskania według różnych procedur i różnych konstrukcji elementu zaciskowego. Przeprowadzono ocenę zewnętrznej powierzchni rury w miejscu zaciskania dla wszystkich próbek według zestawienia przedstawionego $\mathrm{w}$ tabeli 4. Sprawdzenia takiego dokonano przed wykonaniem badań wytrzymałości na ciśnienie hydrostatyczne w temperaturze $80^{\circ} \mathrm{C}$. Ocena wizualna rur w miejscu zacisku przeprowadzona została nieuzbrojonym okiem pod kątem wystąpienia ewentualnych pęknięć, rys i innych uszkodzeń powierzchni rur. Próbki numer 15, 16, 17, według zestawienia przedstawionego w tabeli 4, po wykonaniu operacji zaciskania zostały obcięte w pobliżu miejsca zaciskania, aby umożliwić obserwację wewnętrznej ścianki rury w miejscu zacisku.

Podczas oceny wizualnej nieuzbrojonym okiem zewnętrznej powierzchni rur w miejscu wykonania zacisku nie zaobserwowano ubytków ani defektów (pęknięć, rys) i innych uszkodzeń powierzchni rur. Widoczne były natomiast przebarwienia - jasny odcień rur w miejscach wystąpienia największych naprężeń.

Podczas oceny wizualnej nieuzbrojonym okiem nie zaobserwowano również pęknięć wewnętrznej ścianki rury. Widoczne natomiast były przebarwienia (jasny odcień) rur, jak również pomarszczenia na wewnętrznej powierzchni ścianek rur w miejscach wystąpienia największych naprężeń.

\section{Wyniki z badań wytrzymałości hydrostatycznej}

Po wykonanej operacji zaciskania przygotowano próbki, które kondycjonowano w temperaturze badania w czasie zależnym od średnicy i grubości ścianki rury -6 godzin. Następnie na próbkach tych przeprowadzono badanie wytrzymałości hydrostatycznej zgodnie z PN-EN ISO 1167-1:2007 w temperaturze $80^{\circ} \mathrm{C}$ i naprężeniu obwodowym $11,5 \mathrm{MPa}$. Wyniki zrealizowanych badań wytrzymałości hydrostatycznej przedstawiono w tabeli 8.

Jak wynika z tabeli 8, postawione wymagania zostały spełnione dla wszystkich próbek - dla każdej z nich uzyskano pozytywne wyniki badania. W czasie 165 godzin żadna z próbek nie wykazała pęknięć ani nieszczelności. W przypadku próbek o nr. 1, 2, 3, 4, 10, 11, 12, 13, 14 kontynuowano badania w wydłużonym czasie i żadna z próbek podczas badania nie uległa uszkodzeniu. Wszystkie badania zostały zakończone bez wystąpienia uszkodzenia. 
Tabela 8. Zestawienie wyników badań wytrzymałości hydrostatycznej

Table 8. List of results of hydrostatic strength tests

\begin{tabular}{|c|c|c|c|c|c|c|c|}
\hline \multirow{3}{*}{$\begin{array}{c}\mathrm{Nr} \\
\text { próbki }\end{array}$} & \multirow{2}{*}{\multicolumn{2}{|c|}{ Rodzaj próbki }} & \multirow{3}{*}{$\begin{array}{l}\text { Procedura } \\
\text { zaciskania }\end{array}$} & \multirow{3}{*}{$\begin{array}{c}\text { Ciśnienie } \\
\text { badania } \\
\text { [MPa] }\end{array}$} & \multirow{3}{*}{$\begin{array}{c}\text { Wymagany } \\
\text { minimalny } \\
\text { czas badania } \\
\text { [godz.] }\end{array}$} & \multicolumn{2}{|c|}{ Uzyskane wyniki badania } \\
\hline & & & & & & \multirow{2}{*}{$\begin{array}{c}\text { rzeczywisty } \\
\text { czas badania } \\
\text { [godz.] }\end{array}$} & \multirow{2}{*}{$\begin{array}{c}\text { typ } \\
\text { zniszczenia }\end{array}$} \\
\hline & wymiary & & & & & & \\
\hline 1 & $\mathrm{~d}_{\mathrm{n}} 110, \mathrm{SDR} 11$ & rura & \multirow{5}{*}{1} & 2,30 & 165 & 1165 & brak \\
\hline 6 & $\mathrm{~d}_{\mathrm{n}} 110, \mathrm{SDR} 11$ & rura & & 2,85 & 165 & 168 & brak \\
\hline 12 & $\mathrm{~d}_{\mathrm{n}} 110, \mathrm{SDR} 11$ & rura z podwójnym zaciskiem & & 2,31 & 165 & 858 & brak \\
\hline 4 & $d_{n} 160$, SDR 11 & rura & & 2,37 & 165 & 1000 & brak \\
\hline 14 & $d_{n} 160$, SDR11 & rura + zgrzew + PA/stal & & 2,38 & 165 & 764 & brak \\
\hline 3 & $\mathrm{~d}_{\mathrm{n}} 110, \mathrm{SDR} 11$ & rura & \multirow{4}{*}{2} & 2,30 & 165 & 1165 & brak \\
\hline 5 & $\mathrm{~d}_{\mathrm{n}} 110, \mathrm{SDR} 11$ & rura zaciśnięta płaskownikiem & & 2,30 & 165 & 168 & brak \\
\hline 13 & $\mathrm{~d}_{\mathrm{n}} 110, \mathrm{SDR} 11$ & rura + zgrzew $+\mathrm{PA} /$ stal & & 2,31 & 165 & 1000 & brak \\
\hline 2 & $\mathrm{~d}_{\mathrm{n}} 160, \mathrm{SDR} 11$ & rura & & 2,40 & 165 & 2165 & brak \\
\hline 7 & dn 110, SDR11 & rura & \multirow{5}{*}{3} & 2,37 & 165 & 168 & brak \\
\hline 9 & dn 110, SDR11 & rura + zgrzew $+\mathrm{PA} /$ stal & & 2,36 & 165 & 168 & brak \\
\hline 10 & dn 110, SDR11 & rura z podwójnym zaciskiem & & 2,30 & 165 & 1000 & brak \\
\hline 8 & dn 160, SDR11 & rura & & 2,35 & 165 & 168 & brak \\
\hline 11 & dn 160, SDR11 & rura z podwójnym zaciskiem & & 2,38 & 165 & 1000 & brak \\
\hline
\end{tabular}

\section{Analiza wyników badań}

Proces zaciskania realizowano z różnymi parametrami wynikającymi $z$ różnych procedur badania $-\mathrm{z}$ różnymi temperaturami klimatyzowania przed zaciskaniem $\left(0^{\circ} \mathrm{C}\right.$ i $\left.5^{\circ} \mathrm{C}\right)$, różnymi temperaturami zaciskania $\left(0^{\circ} \mathrm{C}, 5^{\circ} \mathrm{C}\right.$ i $\left.25^{\circ} \mathrm{C}\right)$, różnymi czasami utrzymywania pod zaciskiem (1 godzina, 2 godziny i 8 godzin), różnymi prędkościami zaciskania $(10 \mathrm{~mm} / \mathrm{min}$, $25 \mathrm{~mm} / \mathrm{min}, 50 \mathrm{~mm} / \mathrm{min}$ ) i luzowania (5 mm/min, $12 \mathrm{~mm} / \mathrm{min}$ ) dla techniki zaciskania realizowanej według projektu ST-IGG-2103 i według parametrów ustalonych na podstawie DVGW GW 332. Po całkowitym zluzowaniu zacisku przywracano rurze poliamidowej przekrój kołowy poprzez obrócenie zacisku o 90 stopni w stosunku do zaciskanego miejsca i częściowe zaciśnięcie rury. $\mathrm{W}$ tym przypadku również były zastosowane różne prędkości ( $50 \mathrm{~mm} / \mathrm{min}$ i $12 \mathrm{~mm} / \mathrm{min}$ ). Po zaciskaniu według PN-EN 12106:2002 zgodnie z procedurą rury nie były przywracane do kształtu kołowego.

Podczas oceny wizualnej zewnętrznej powierzchni rur nieuzbrojonym okiem dla żadnej z próbek (próbki o numerach 1-17) nie zaobserwowano pęknięć, rys ani innych uszkodzeń powierzchni rur w miejscu zaciskania. Widoczne były natomiast przebarwienia (jasny odcień) rur w miejscach wystąpienia największych naprężeń w trakcie procesu zaciskania.

Zaobserwowane podczas oceny wizualnej przebarwienia nie różnią się od tych, które występują podczas badań odporności rur PE na zaciskanie według PN-EN 12106:2002 oraz według projektu ST-IGG-2103.

Podczas oceny wizualnej nieuzbrojonym okiem wewnętrznej powierzchni rur (próbki o numerach 15-17) nie zaobserwowano pęknięć wewnętrznej ścianki rury. Widoczne były natomiast przebarwienia (jaśniejszy odcień) rur, jak również lekkie pomarszczenia na wewnętrznej powierzchni ścianek rur w miejscach wystąpienia największych naprężeń niezależnie od parametrów procesu zaciskania. Pozytywne wyniki badania wytrzymałości na ciśnienie wewnętrzne wskazują, że występujące przebarwienia na zewnętrznej powierzchni rur i pomarszczenia wewnętrznej powierzchni rury nie mają wpływu na wytrzymałość hydrostatyczną.

Wszystkie wytypowane do badań próbki rur, w tym próbki z podwójnym zaciskiem, rury ze zgrzewem doczołowym oraz ze zgrzewem i połączeniem PA/stal, poddane procesowi zaciskania zgodnie $\mathrm{z}$ procedurami określonymi w normie PN-EN 12106:2002, w projekcie ST-IGG-2103 p. 3.2 oraz według parametrów ustalonych na podstawie wytycznych DVGW GW 332 uzyskały pozytywne wyniki badania wytrzymałości hydrostatycznej w $80^{\circ} \mathrm{C}$.

Analizując otrzymane wyniki badań odporności badanych próbek na zaciskanie (po próbie wytrzymałości hydrostatycznej), można stwierdzić, że zaciskanie, bez względu na parametry tego procesu, nie spowodowało obniżenia ich wytrzymałości na ciśnienie wewnętrzne. 


\section{Wnioski}

1. Badania próbek rurowych po zaciskaniu wykazały odporność rur z poliamidu na tego typu operacje. Rury z PA 12 charakteryzują się porównywalną odpornością na zaciskanie z rurami polietylenowymi klasy PE 100. Przeprowadzona ocena wizualna rur po operacji zaciskania pozwala potwierdzić brak wpływu zaciskania na wyniki odporności na ciśnienie wewnętrzne.

2. Nie zaobserwowano zmniejszenia wytrzymałości rur PA 12 na ciśnienie wewnętrzne pod wpływem odkształceń powstałych w trakcie zaciskania rur PA 12. Można stwierdzić, że wykonane operacje zaciskania nie mają istotnego wpływu na wytrzymałość gazociągu budowanego z rur PA 12, a zatem na bezpieczeństwo jego użytkowania.

3. Przyrząd do zaciskania wykorzystywany do realizowania procedury zaciskania na rurociągu pod ciśnieniem powinien posiadać mechanizm wywołujący większą siłę ściskającą od tych używanych standardowo do zaciskania rur polietylenowych, najlepiej z agregatem hydraulicznym.

Artykuł powstał na podstawie pracy statutowej pt.: Ocena możliwości stosowania zamykania przeplywu gazu metoda zaciskania rur z poliamidu PA12 dla gazociagów o maksymalnym ciśnieniu roboczym $M O P=1,6 \mathrm{MPa}$ - praca INiG - PIB na zlecenie MNiSW; nr zlecenia: 0055/GP/18/01, nr archiwalny: DK-4100-55/18.

\section{Literatura}

Baranowski W., 2009. Wybrane właściwości rur PE-HD po zamknięciu przekroju przez zaciskanie podczas konserwacji lub naprawy rurociągu. Przetwórstwo Tworzyw, 15 (3): 89-97.

Bilsing A., Müller-Syring G., Wenzel M., Postma P., 2018. Zum Abquetschen und Rückrunden von Kunststoffrohren. Energii, Wasser-Praxis 1.

Dowe A., Baron Ch., Rieck P., Buessing R., Rameil M., 2011. Rury z poliamidu 12: właściwy wybór dla instalacji bezwykopowych. Inżynieria Bezwykopowa, 3: 82-86.

Klupa A., Szewczyk P., 2009. Wpływ zamykania przepływu metodą zaciskania na wytrzymałość hydrostatyczną gazociągów polietylenowych. Nafta-Gaz, 3: 243-247.

Lewandowski G., Rytwińska E., Milchert E., 2006. Właściwości fizyczne i zastosowanie poliamidu 12. Polimery, 51 (11-12): 829-835.

Szewczyk P., 2018. Ciśnieniowe próby szczelności gazociągów z tworzyw sztucznych o MOP 1,6 MPa. Nafta-Gaz, 5: 386-390. DOI 10.18668/NG.2018.05.06.
Wuest J., Wenzel M., Bilsing A., Postma P., Wessing W., 2018. Squeeze-off and rerounding of plastic pressure pipes. Proceedings of the $19^{\text {th }}$ Plastic Pipes Conference PPXIX. Las Vegas, Nevada, 24-26.09.2018.

\section{Akty prawne i normatywne}

prCEN TS12007-X:2018 Gas infrastructure. Pipelines for maximum operating pressure up to and including 16 bar. Part X: Specific functional requirements for polyamide (MOP up to and including 16 bar)

DVGW GW 332:2001-09 Abquetschen von Rohrleitungen aus Polyethylen in der Gas- und Wasserverteilung (Polietylenowe rury gazociągowe i wodociągowe umożliwiające zamykanie przepływu metodą zaciskania)

ISO 16486-2:2012 Plastics piping systems for the supply of gaseous fuels - Unplasticized polyamide (PA-U) piping systems with fusion jointing and mechanical jointing - Part 2: Pipes.

ISO 16486-6:2012 Plastics piping systems for the supply of gaseous fuels - Unplasticized polyamide (PA-U) piping systems with fusion jointing and mechanical jointing - Part 6: Code of practice for design, handling and installation.

PN-EN ISO 1167-1:2007 Rury, kształtki i zestawy z termoplastycznych tworzyw sztucznych do przesyłania płynów. Oznaczanie wytrzymałości na ciśnienie wewnętrzne. Część 1: Metoda ogólna.

PN-EN 12007-2:2013-02 Infrastruktura gazowa. Rurociagi o maksymalnym ciśnieniu roboczym do 16 bar włącznie. Część 2: Szczegółowe wymagania funkcjonalne dotyczące polietylenu (MOP do 10 bar włącznie).

PN-EN 12106:2002 Systemy przedmiotów rurowych z tworzyw sztucznych. Rury z polietylenu (PE). Metoda badania wytrzymałości na ciśnienie wewnętrzne po zastosowaniu zacisku.

PN-EN 1555-2:2012 Systemy przewodów rurowych z tworzyw sztucznych do przesyłania paliw gazowych. Polietylen (PE). Część 2: Rury.

prST-IGG-2103 Gazociągi dystrybucyjne. Warunki techniczne zamykania przepływu w gazociągach z polietylenu metodą zaciskania. Wymagania i zalecenia.

Mgr inż. Anna WRÓBLEWSKA
Starszy specjalista badawczo-techniczny w Zakładzie
Przesyłania i Dystrybucji Gazu - Laboratorium
Tworzyw Sztucznych
Instytut Nafty i Gazu - Państwowy Instytut Badawczy
ul. Lubicz 25 A, 31-503 Kraków
E-mail: anna.wroblewska@inig.pl

